\title{
Erratum to: Students' conceptions about the greenhouse effect, global warming, and climate change
}

\author{
D. P. Shepardson • S. Choi • D. Niyogi • U. Charusombat
}

Published online: 12 May 2012

(C) Springer Science+Business Media B.V. 2012

\section{Erratum to: Climatic Change \\ DOI 10.1007/s10584-009-9786-9}

Our first study appeared in Climatic Change ("Students' conceptions about the greenhouse effect, global warming, and climate change" Shepardson et al, Climatic Change (2011) 104:481-507 DOI 10.1007/s10584-009-9786-9) reporting an investigation of secondary students' (grades 7-12) conceptions. Our second study, "Seventh grade students' conceptions of global warming and climate change," focused on seventh grade students and was published in Environmental Education Research (Environmental Education Research (2009) 15: 5, 549-570 DOI: 10.1080/13504620903114592). Unexpectedly, the first study was published after the second. The Climatic Change article should have indicated that it served as the foundation for the Environmental Education Research article; and the Environmental Education Research article should have indicated that it built on the Climatic Change study. A similar notice will appear in Environmental Education Research.

The online version of the original article can be found at http://dx.doi.org/10.1007/s10584-009-9786-9.

D. P. Shepardson $(\bowtie) \cdot$ S. Choi

Department of Curriculum and Instruction, Purdue University, 100 North University Street,

West Lafayette, IN 47907-2098, USA

e-mail: dshep@purdue.edu

D. P. Shepardson · D. Niyogi $\cdot$ U. Charusombat

Department of Earth and Atmospheric Sciences, Purdue University,

West Lafayette, IN 47907-2051, USA 